\title{
Exploring English Language Teachers' Challenges and Coping Strategies in Teaching Slow Learners in Inclusive Education Programmes
}

\author{
Fathiah Syahirah Khalid \\ Kulliyyah of Education, \\ International Islamic University Malaysia \\ fathiah.syahirah206@gmail.com
}

\begin{abstract}
It has been reported that English as a second language (ESL) teachers are not trained well enough to teach slow learners in inclusive education. The aim of this study is to explore the challenges that Malaysian English language teachers face in teaching slow learners in the inclusive educational program and to determine their coping strategies. The present study employed a qualitative research method with case study design through face-to-face interviews with three English language teachers from three secondary schools in Malaysia. Five major themes were found through thematic analysis. External and internal factors represented the challenges the teachers faced in teaching slow learners in inclusive education, while teaching resources, remedial activities, and teachers' skills represented the coping strategies used by the English language teachers.
\end{abstract}

Keywords: English language teachers, slow learners, inclusive education, coping strategies, case study method

\section{INTRODUCTION}

Several studies on students with special educational needs (SEN) (e.g., Abdollah, Ahmad \& Akhir, 2010; 2012; Alias, Alias, Ibrahim \& Jalaluddin, 2013) highlighted the importance of focusing on the teaching and learning process with these students. Students with SEN are those who have special auditory, visual or learning disabilities (LDs) as stated in the Malaysia Education Act 1996 and cited in Jelas and Ali (2014). Students with LDs in the Malaysian educational context refer to students with different kinds of LDs, and this includes slow learners (Abdollah et al., 2010). Slow learners as defined by Malik, Rehman and Hanif (2012) are students who attain intelligence scores lower than the average test scores. These students have learning abilities different from those of normal students and cannot meet average academic standards. In other words, slow learners are students who have lower intelligence scores than normal students and whose learning abilities are different from those of normal students. This definition of slow learners is used throughout this study.

The Ministry of Education (MOE) Malaysia introduced the Inclusive Educational Programme (IEP) as one of the efforts to address the educational needs of slow learners and other students with LD needs. The programme has been implemented in selected primary, secondary and post-secondary government schools in Malaysia (Bandu \& Jelas, 2012). It is an 
initiative from the MOE Malaysia to provide equal educational chances for every student, as well as being one of the aspirations in the Malaysia Education Blueprint 2013-2025 (Ministry of Education Malaysia, 2013a). The IEP is defined as "an educational programme for a pupil with special educational needs, which is attended by a pupil with special educational needs together with other pupils in the same class in a government school or government-aided school" (Ministry of Education Malaysia, 2013b, p.10). It emphasises that students with LDs and normal students receive their education in the same class. Undoubtedly this initiative encourages equality between these two groups of students. However, at the same time, it poses a challenge to some teachers, particularly those teaching English, as a majority of the learners are not first language speakers of English. But given the importance of English in Malaysia, students of all abilities have no choice but to learn it as a school subject.

Students in the IEP are of different academic abilities. Thus teachers have encountered various problems in teaching these students. In a study involving autistic children within an inclusive classroom setting, Zuki and Rahman (2016) discovered challenges related to cognition and managing student behaviour. Additionally, the teachers faced language and communication problems in classroom instruction. A study conducted by Nasir and Effendi (2016) discovered a host of other challenges: a lack of appropriate teaching resources, early intervention programs, essential facilities, readiness to work with special children and teaching materials. These are the challenges faced by teachers when teaching special needs students in the IEP. In Chimhenga (2017), teachers of dyslexic children experienced difficulties caused a lack of instructional resources, a lack of skills in managing special needs students, and large classes. Slow learners represent one category of students in the IEP. A major characteristic of these learners is that they have little interest in learning and schooling (Arini, Choiri \& Sunardi, 2017). Maintaining their learning interest, as discovered by Hadi (2016), is a daunting challenge for teachers. A study conducted by Shaw (2010) revealed that large class sizes is the problem teachers encountered when teaching slow learners in IEP. This is also one of the findings of Mirani and Chunawala (2015). They found that large classes, time constraints and an extensive syllabus are the problems that teachers faced in teaching slow learners in an inclusive classroom. In addition, a lack of exposure and training on guiding slow learners posed some difficulties to teachers (Yadav, 2016).

One of the theories related to helping slow learners in their learning process is Reuven Feuerstein's Mediation learning experience (MLE) theory. Feuerstein proposed that mediation is important for students to fully benefit from either formal or informal learning (Seng, 2003). This shows that mediation from parents, teachers or friends is crucial in the learning process. MLE was defined by Tzuriel (2001) as "an interactional process in which an adult interposes him or herself between the child and a set of stimuli and modifies them by affecting their frequency, order, intensity, and context" (p.24). The MLE theory originally emerged from cases of mental retardation or emotional disturbance, and was later extended to include students from various learning abilities and backgrounds (Tzuriel, 2001). The strength of the theory is that it focuses on what students are capable of doing rather than on their disabilities. In the case of slow learners, Feuerstein believed that teachers should exert an effort on developing their abilities instead of highlighting what they cannot do or accomplish. This idea is supported by Presseisen and Kozulin (1992), who emphasized the position of mediation in human learning. They were of the view that children learn about a harmful stimulus through a complex process of mediated learning, which occurs with mothers or caretakers and not through direct experience with the stimulus. They pointed out that learning through direct exposure to stimuli and learning directed by human beings are two entirely different forms of learning. 
According to Feuerstein, an individual's cognitive development is influenced by the quality of his/her interaction with the environment through "intentional human beings" (Seng, 2003). Seng (2003) defined "intentional human beings" as teachers. In other words, he opined that the quality of an interaction between students and the environment, which is mediated by teachers impacts on students' cognitive development. Feuerstein (1990; as cited in Seng, 2003) believed that genetics is not the only factor that influences one's ability to learn. In addition, Tzuriel (2001) noted that Feuerstein in this theory had three main viewpoints. Firstly, he agreed that an individual's cognition is modifiable and adaptable to demands in the environment. In other words, the environment to some extent is related to an individual's cognition. Secondly, the modifiability of human cognition can be found in all individuals regardless of age, etiology, and severity of condition. Lastly, Feuerstein also believed that MLEs are more beneficial in the process of modification than unmediated experiences. In short, he believed mediated experiences have more impact on the modification of one's cognition than unmediated ones. In addition, interaction that occurs between a mediator and a child also improves and/or creates cognitive functions in the child's cognition (Tzuriel, 2001).

In the Malaysian educational context, all English language teachers including the mainstream ones are responsible for teaching the language in the IEP. Some of them have not had any proper exposure and training to teach students in this programme. An observation was made by Paul (2016) that ESL teachers, as well as teachers of other subjects, often lack the skills of supporting slow learners. This is a setback that can lead to subsequent problems in the teaching and learning process if not carefully addressed. Teachers who are not well-trained in teaching these students may not notice the problems and choose to stop teaching them. As a result, these students are neglected in the class and may end up finding learning uninteresting. They might also feel that going to school is worthless, thus deciding to skip school. Therefore, education stakeholders must address this issue to avoid further problems, including literacy and social problems amongst students.

Teachers of slow learners in the IEP or those identified as one of the mediators in the MLE theory must be exposed to the realities of teaching slow learners. However, most previous studies have not specifically examined the teaching of English to slow learners. Their focus has been general rather than specific (e.g. Abdollah et al., 2010, 2012; Alias et al., 2013; Bandu \& Jelas, 2012; Borah, 2013). The literature does not contain enough information on how English should be taught to slow learners in the IEP context, and the challenges such an endeavor brings. Hence, this study aims to fill the gap by focusing on the challenges English language teachers face when teaching slow learners in the IEP. The study was conducted with the hope of helping teachers, school administrators and education stakeholders to get an understanding of the challenges that confront the teachers of English within an IEP setting so that necessary efforts can be taken to ensure greater success in the teaching and learning process. It also aims to explore the strategies teachers use to overcome the challenges so that other teachers can adopt the strategies when teaching students in the same setting.

\section{METHODS}

\section{Setting and Design}

This exploration followed a critical inquiry case study design to generate in-depth findings on the challenges confronting English teachers when teaching slow learners in an inclusive classroom, and the strategies they used to cope with the challenges. 


\section{Participants and Participant Selection}

Three English language teachers from three different secondary schools located in Kuala Lumpur, Malaysia were selected as the participants through a purposive sampling technique. Purposive sampling was used in this study to ensure that the participants involved had the information that this study aimed to explore. The participants were sought based on two criteria. The first criterion was that they must be teaching English in an inclusive classroom that comprised different levels of ability. The second criterion was that there were slow learners in their class. All of the participants involved in this study are female. The first participant, in her forties, is an Indian. Meanwhile, the second and third participants, in their thirties, are both Malay. All of the participants had a degree in teaching English language, but not in special education. They also had more than four years of experience in teaching English language in schools. They had been teaching English language to slow learners in inclusive classrooms for at least one year. The first participant teaches English to thirteen to fifteen-year-old students. The second and third participants teach English to students who are sixteen to seventeen years old.

\section{Instrument}

The data was obtained through three different semi-structured interview sessions. Each interview session lasted for not more than 30 minutes. A protocol consisting of ten questions were used in the interview sessions. The researcher also asked follow-up questions that were relevant to participants' responses. The interview guide used in this study is attached in the appendix.

\section{Data Collection}

Firstly, information on the inclusive educational programme in School A was gathered from an English language teacher of School A via phone calls. It was done to confirm that the teacher had the two criteria decided a priori (i.e., teaching English language in an inclusive classroom with slow learners in their class). The teacher was informed of the purpose of this study. The same process was followed to approach the English language teachers in Schools B and C. The researcher conducted face-to-face interviews with the participants after agreeing on the venue, date and time. The interview sessions were conducted at a place with minimal disturbance in order to ensure the clarity of the video and audio. Each interview session lasted for not more than 40 minutes.

\section{Data Analysis}

A thematic analysis was used in the data analysis. Verbatim transcriptions of each interview were made by the researcher. All transcriptions were read thoroughly before they were systematically coded. In this process, any unwanted information was deleted. The participants' answers were categorised under several codes, which comprised small meaningful units of data available in the transcriptions. After all the information in the transcriptions had been coded, the researcher grouped the codes into categories based on their similarities. Lastly, categories that were related to each other were grouped into themes. To ensure the trustworthiness and credibility of the data, the researcher applied the technique of member check. She submitted the interview transcriptions to each participant to ensure that what had been transcribed correctly represented what the participants intended to convey. 


\section{FINDINGS}

\section{Challenges Faced by English Teachers in Teaching Slow Learners in IEP}

Eleven categories emerged from the raw data of challenges faced by English teachers when teaching slow learners in IEP, and these were further categorized into two general themes, i.e. internal and external factors. They are presented in Table 1.

Table 1

Internal and External Challenges Faced by English Teachers When Teaching Slow Learners in IEP

\begin{tabular}{ll}
\hline Themes & Categories \\
\hline Internal Factors & $\begin{array}{l}\text { Student participation, student effort, students' academic } \\
\text { performance, identifying slow learners, students' } \\
\text { attention span, students' inability to understand } \\
\text { teachers' instructions, students' low learning rate }\end{array}$ \\
External Factors & $\begin{array}{l}\text { Teaching process, training for teachers, classroom } \\
\text { setting, language barrier, parents' reluctance }\end{array}$ \\
\hline
\end{tabular}

\section{Internal Factors}

The theme of internal factors refers to the challenges that the participants face in the IEP which are related to the slow learners' behavioral and cognitive problems. Seven types of internal factors were found in this study. The first internal factor is student participation. Both the first and the second participants faced this type of challenge. The first participant mentioned that some of the slow learners in her IEP refused to give responses and participate in some of the class activities. This can be deduced from the first participant's statement:

"But then, if they've to perform something like written works or come in front and talk about something, you know...it's difficult. It's difficult."

The second teacher pointed out that sometimes they simply refused to do the assigned tasks:

"Sometimes they refused to do work..."

The second type of internal factor is the lack of student's effort. The first participant also said slow learners' refusal to try to improve themselves is a challenge for her, as she has to ensure that slow learners have understood a lesson before proceeding to the next topic or lesson. The participant mentioned that:

"Then...emm...some students they still...they are same. They still don't want to do anything. That's difficult, I think."

Slow learners' academic performance is also another internal factor challenge found in this study. Both the first and second participants reported this challenge during the interviews. They pointed out that some of the slow learners performed poorly on their examinations. One of the participants said: 
"For example ... .emm...how to say...like writing composition...essay...they find it like...emm...very difficult, so they'll like leave the page empty. So, those are the challenges...great challenges actually."

This is challenging for the participants as they could not measure the students' level of understanding, and this does not meet the school requirements to ensure good results among students.

The next internal factor challenge found in this study is identifying slow learners in the inclusive classroom. The first and the second participants pointed out that it is difficult for them to identify slow learners in IEP because the inabilities of slow learners vary across individuals. One of the participants said:

"So, it is not to say that if a person is aaa...weak in English language, it doesn't mean that the student is also weak in others."

Another type of internal factor challenge found in this study is related to slow learners' attention span. The first participant mentioned that it is difficult for her as an English language teacher to sustain her slow learners' interest throughout the teaching and learning process. She said:

"As I said earlier, sustaining their interest, sustaining their time...in learning...for a longer period is definitely difficult."

The problem related to slow learners' ability to follow instructions is another type of internal challenge faced by the participants. The second and third participants reported that slow learners have problems in understanding the instructions given them. This is a challenge for the participants as they need to spend more time explaining the instructions in their class. As the third participant said:

"They are actually...they...they are not...aaa...into the task, they don't understand what they're supposed to do."

When slow learners do not understand what they have to do, they will do something else like talking to their friends, which disturbs the teaching and learning process.

The next internal challenge faced by the participants is slow learners' learning rate. This can be illustrated through one of the participants' statement:

"Because, normally, most of time, trust me...I'm being honest as a teacher, he's..he's left...a bit left."

She mentioned that slow learners in her IEP are left behind and she needs to carefully plan the lesson to cater to their needs.

\section{External Factors}

External factor challenges faced by the participants refer to challenges in delivering lessons to slow learners in the inclusive classroom. The first type of external factor challenge is related to the teaching process. The participants had to spend more time to prepare teaching and learning materials and to discuss the lesson with the slow learners. These problems were reported by all participants in this study. As one of the participants said: 
"Of course Another external factor challenge is related to teacher training. The third participant mentioned that English language teachers who teach in IEP do not receive proper training in teaching students with SEN and thus they do not know the suitable way to teach these students. She said:

"So, I think need that, but...I would say, you know...they really need help because we're not trained to teach this kind of students."

An external problem of classroom setting was also found in this study. The mixed abilities and large class size caused difficulties for the participants in teaching English language to slow learners in the inclusive classroom. For example, one of the participants said:

"In one class, you have from advanced, medium to intermediate, to slow learners, of course it's gonna be a challenging task to do."

The next external problem found in this study is related to the language used. The first teacher mentioned that slow learners having a mother tongue other than English caused difficulties in classroom instruction. She added that some did not understand what was being said by her and thus she needed to spend more time in the class explaining a topic or lesson. The second and third participants also mentioned the same problem. The learners in their class did not understand English and thus did not understand what had been taught. As the third participant said:

"Because it's a rural area, even he's a Chinese student, but he can't even understand Malay. He hardly understands English."

Parents' reluctance is also another external problem found in this study. The first participant mentioned that some of the slow learners' parents do not acknowledge the learning problems faced by their children and they are reluctant to allow their children to be in the special education class. It can be illustrated through her statement below:

"Based on my experience for the past twenty four years of teaching... emm..sorry...many parents are reluctant to acknowledge that the kids are slow learners."

\section{Coping Strategies Used by English Teachers in Teaching Slow Learners in IEP}

Seven categories emerged from the raw data on coping strategies used by English teachers in teaching slow learners in IEP and were further categorized into three general themes.

Table 2

Coping Strategies Used by English Teachers in Teaching Slow Learners in IEP

\begin{tabular}{ll}
\hline Themes & Categories \\
\hline Teaching resources & Technology, visual aids \\
Remedial activities & $\begin{array}{l}\text { Enrichment tasks, spend more } \\
\text { time, give treatment }\end{array}$ \\
Teacher's skills & $\begin{array}{l}\text { Teaching approach, teaching } \\
\text { manner, attention }\end{array}$ \\
\hline
\end{tabular}




\section{Teaching Resources}

The participants coped with the challenges by using varied teaching resources. They reported using two types of resources. The first and third participants used technology to attract their slow learners. As the first participant reported:

"For example, emm...I've taught students learning through songs, music...that capture them, you see."

The next type of teaching resource is visual aids. One of the participants used pictures when teaching English language to their slow learners. She said:

"And I help them with certain guidance works, pictures..."

\section{Remedial Activities}

Remedial activities refer to the additional activities that the participants do with their slow learners in IEP. In order to cope with the mentioned challenges, the first and third participants provide remedial activities to their slow learners. There are three types of remedial activities practiced by the two participants. The first type of remedial activity is enrichment activities. The first participant gives extra exercises to slow learners in her class, especially when they are going to sit for their examinations. The first participant said:

"So, usually to train them towards the end of the examination, what I do...I give them practices after each skill...ahaa...each skill."

Another remedial activity is spending more time with slow learners. The third participant used her students' free time to explain further about a particular lesson to her slow learners, while the first participant gave extra classes. She said:

"It is a bit of a sacrifice on my part...For example, during my recess time, I call those students who are interested to do extra work. They come to my room."

The third participant also gave focus group treatment to her slow learners, frequently spending specific time with her slow learners to help them. She said:

"What do I normally do, yeah, call the person individually."

\section{Teacher Skills}

The next coping strategy is related to the participants' teaching skills. There are two types of teaching skill found in this study. The first type is teaching approach and is found in all of the three participants. The second participant for example, always focuses on her slow learners first in a lesson. As she said:

"You know, when we go to class, we tackle them first."

The first participant on the other hand, emphasizes that she always gives feedback to her slow learners. This can be illustrated in the following statement:

"After that, when they give you the task, like written works etc, like examinations, the teachers should have some kind of feedbacks and reaching up the students after the class." 
The next type of teacher skill is related to teaching manner. This coping strategy is used by both the first and third participants. The first participant uses pleasant words when talking to her slow learners. She said:

"And even sometimes you tell to do, you have to be too nice to them. "Akaak, tolong buat"...You know?"

The third participant says in order to cope with the challenges she always has positive perceptions towards her slow learners. She says it is important for her to believe in her students. As she said:

"But the most important thing, you've got to believe in the students."

\section{DISCUSSION}

The findings show that there are various types of challenges faced by the participants in teaching English language to slow learners in the inclusive classroom. One of the types of challenges faced by participants in this study is internal factor challenges. This type of challenge is related to students' learning abilities. It was found that slow learners' reluctance to get involved in classroom activities causes difficulties to the participants. Zuki and Rahman (2016), on the other hand, found over involvement and isolation of autistic students are the challenges that their participants face in teaching autistic students in the inclusive classroom. Internal factor challenges such as slow learners' academic performance and participation in classroom activities were also found in the study conducted on challenges in teaching students with literacy and numeracy problems (Mumpuniarti, 2017).

On the other hand, the findings on internal factor challenges are opposite to the findings found in studies conducted by Vorapanya, Sermsap, Dunlap, and Diane (2014), Thwala (2015) and Gandiya (2016) on challenges faced by teachers of special need students. Their respondents and participants did not reveal any internal challenges in teaching students with SEN in inclusive education. There were only external challenges found in their studies. Differences in educational contexts might explain the different findings found in their study. External challenges were found in many studies on inclusive education. Large class size and lack of teaching resources, for example, were also found in the studies conducted by Zuki and Rahman (2016), Thwala (2015) and Gandiya (2016). Also, the external factor challenge related to lack of training was also widely discussed in many studies on teachers' challenges in teaching students with SEN in inclusive education (e.g. Sharma, Forlin, Deppeler and Guang-xue, 2013; Mangope, Mannathoko and Kuyini, 2013; Thwala, 2015). Opposite to current findings, the study conducted by Vorapanya, Sermsap, Dunlap, and Diane (2014) in the Thai educational context found that lack of financial support was also one of the challenges that teachers of students with SEN faced.

In regard to the context of teaching English language, the language barrier is a challenge for the participants as slow learners are not able to understand English as it is not their mother tongue. It was also one of the environmental problems found in study conducted by Zuki and Rahman (2016). They mentioned that some of the autistic students do not understand the main languages used in the classroom. External challenges faced by the participants in the present study are in line with what is emphasized in Feuerstein's MLE theory. Tzuriel (2001) explained Feuerstein's three main viewpoints. One of his viewpoints is he agrees that an individual's 
cognition is modifiable and adaptable to demands from the environment. In other words, environment to some extent is related to an individual's cognition. The importance of environment in a mediation process, therefore explains why the teachers faced challenges that are related to external factors.

Challenges in teaching English language to slow learners in inclusive classrooms do not stop the English teachers from teaching the language to the students. They used many strategies to cope with the challenges. Using technology and other visual aids are among the coping strategies reported by the participants. These strategies are in line with the findings found in Mumpuniarti's (2017) study. Using technology is also similar to what was reported by music teachers teaching student with special needs (Manning, 2016). However, other studies revealed different findings. Paul-Fitzpatrick's (2014) study on mainstream teachers teaching students with LDs, for example, did not find the coping strategy of varying teaching resources.The participants in this study also provided enrichment activities, special treatment, and spent more time with their slow learners. Similarly, studies conducted by Paul-Fitzpatrick (2014) also found that teachers of students with LDs exposed the students to literacy programmes as one of the teaching strategies. Kocyigit and Artar (2015), on the other hand, found that their participants did not provide remedial activities to their visually impaired students, but used support from parents and friends as their coping strategy. Likewise, the strategy of peer support was also found in Uzair-ul-hassan, Hussain, Parveen, and Souza (2015). Both the coping strategies of varying teaching resources and providing remedial activities are related to Feuerstein's MLE theory. Feuerstein emphasized that in a process of modification, mediated experiences are more beneficial than those that are unmediated.

In addition, the participants also emphasized that they used their teaching skills as their coping strategies. In line with the findings, participants in Wong and Chik (2016) also reported that they used smaller steps and slower pace in teaching music to students with SEN. The current study's findings also revealed that the participants used coping strategies that are related to their teaching manner. They talk to their slow learners using polite and pleasant words and this is similar to one of the coping strategies found in Mumpuniarti. However, the coping strategy of using pleasant words was not found in a study conducted by Udoba (2014). The researcher found that teachers of students with developmental disability use help from parents and guardians, friends, small groups, picture drawings, and positive reinforcement in order to cope with the challenges of teaching the students in inclusive classrooms. The use of the teaching skill coping strategy is also emphasized in Feuerstein's MLE theory. Feuerstein indicated that cognitive development of an individual is also influenced by the quality of interaction between an individual and the environment through an "intentional human being" (Seng, 2003). Seng (2003) defined "intentional human being” in Feuerstein's MLE theory as the teacher.

\section{CONCLUSION}

This study has revealed some interesting findings on English language teachers' challenges in teaching slow learners in inclusive classrooms. First, the study finds that there are various types of challenges faced by the English language teachers in inclusive classrooms. There are both internal and external challenges. Lack of participation from students, poor academic performance, identifying the slow learners, slow learners' low attention span, and slow learners' low learning rate are the challenges related to internal factors. These challenges are mainly due to the slow learners' low cognitive ability, which leads to some learning problems. 
In addition, lengthy teaching process, lack of teacher training, improper class setting, language barrier, and parents' reluctance are the external challenges. Language barrier can be considered as a double-barrelled challenge because English language teachers not only have to ensure slow learners understand a particular lesson, but also the language used. The findings also provide insight to other teachers on the realities of teaching slow learners in inclusive classrooms so that they can be well prepared to teach slow learners. Most importantly, they show that English language teachers are still struggling to teach slow learners in inclusive classrooms. It is therefore important for education stakeholders to take necessary actions to overcome the challenges. It is suggested that mainstream teachers teaching slow learners be given proper training to teach these students. A conducive classroom setting should also be available to ensure effective teaching and learning.

In addition, coping strategies used by the participants were also highlighted in this study. The coping strategies found in this study support what Feuerstein emphasised in his MLE theory. He proposed that mediation is important for students to fully benefit from either formal or informal learning (Seng, 2003). The use of various teaching resources, initiatives to provide remedial activities to slow learners, and good teaching skills show how mediation can be used with slow learners. The coping strategies used by the participants give some guidance to other teachers in teaching slow learners. However, this study is only a preliminary study, which only focuses on a small number of teachers in Kuala Lumpur, Malaysia. Hence, additional research is needed to explore the challenges that English language teachers from other contexts face in teaching slow learners in inclusive classrooms. Undoubtedly, many improvements could be made by parents, teachers, and education stakeholders to ensure successful learning for all students. 


\section{REFERENCES}

Abdollah, N., Ahmad, W.F.W. \& Akhir, E.A.P. (2010). Multimedia courseware for slow learners: A preliminary analysis. In Information Technology (ITSim), 2010 International Symposium in (Vol. 1, pp. 1-6). IEEE. Retrieved from http://ieeexplore.ieee.org/document/5561365/

Abdollah, N., Ahmad, W.F.W. \& Akhir, E.A.P. (2012). Development and usability study of multimedia courseware for slow learners: 'Komputer saya'. In Computer \& Information Science (ICCIS), 2012 International Conference on (Vol. 2, pp. 1110-1114). IEEE. Retrieved from http://ieeexplore.ieee.org/stamp/ stamp.jsp?arnumber= 6297192

Alias, R., Alias, N. A., Ibrahim, A. B., \& Jalaluddin, J. (2013). Proposed technology solutions for Special Educational Needs (SEN) learners: Towards inclusive education in Malaysian universities. International Journal of Information and Education Technology, 3(2), 206.

Arini, F.D., Choiri, A.S. \& Sunardi. (2017). The use of comic as a learning aid to improve learning interest of slow learner student. European Journal of Special Education Research, 2(1), 71-78. Retrieved from https://oapub.org/edu/index.php/ejse/article/ view/415

Bandu, S.H. \& Jelas, Z.M. (2012). The IEP: Are Malaysian teachers ready? Procedia - Social and Behavioral Sciences 47, 1341-1347. Retrieved from https://www.researchgate. net/profile/Sitti_Bandu/publication/271880985_The_IEP_Are_Malaysian_Teachers_ Ready/links/563f69a208ae8d65c0150ce4/The-IEP-Are-Malaysian-TeachersReady.pdf

Borah, R. R. (2013). Slow learners: role of teachers and guardians in honing their hidden skills. International Journal of Educational Planning \& Administration, 3(2), 139-143. Retrieved from https://www.ripublication.com/ijepa/ijepav3n2_04.pdf

Chimhenga, S. (2017). Teaching learners with reading difficulties in an inclusive setup in Zimbabwe: challenges and solutions. IJRDO-Journal of Educational Research, 2(2), 168-179. Retrieved from http://www.ijrdo.org/International-Journal-of-Research-\&Development-Organisationpdf/Journal\%20of\%20Educational\%20Research/February2017/Educational\%20Research-February-2017-13.pdf

Gandiya, B.T. (2016). Challenges faced by lecturers in implementing inclusive education in tertiary education: a case of Botho university. Retrieved from http://repository. bothouniversity.ac.bw/buir/bitstream/handle/123456789/168/Bernard\%20Inclusive\%2 0Education\%20(1).pdf?sequence $=1$

Hadi, F.R. (2016). Proses pembelajaran matematika pada anak slow learners (lamban belajar). Premiere Educandum, 6(1), 35-41. Retrieved from http://ejournal.unipma.ac.id/ index. $\mathrm{php} / \mathrm{PE} / \mathrm{article} / \mathrm{view} / 295$ 
Jelas, Z.M. \& Ali, M.M. (2014). Inclusive education in Malaysia: Policy and practice. International Journal of Inclusive Education, 18(10), 991-1003. Retrieved from https://www.researchgate.net/publication/254242626_Inclusive_Education_in_Malays ia_Policy_and_Practice

Kocyigit, N. \& Artar, P. S. (2015). A challenge: teaching English to visually-impaired learners. Procedia - Social and Behavioral Sciences, 199, 689 - 694. Retrieved from http://www.sciencedirect.com/science/article/pii/S1877042815046182

Malik, N. I., Rehman, G. \& Hanif, R. (2012). Effect of academic interventions on the developmental skills of slow learners. Pakistan Journal of Psychological Research, 27(1), 135-152. Retrieved from http://www.pjprnip.edu.pk/pjpr/index.php/pjpr/article/ viewFile/37/29

Mangope, B. \& Kuyini, A. B. (2013). Pre-service physical education teachers and inclusive education: attitudes, concerns and perceived skill needs. International Journal of Special Education, 28(3), 82-91. Retrieved from https://files.eric.ed.gov/fulltext/ EJ1024424.pdf

Manning, I. (2016). Music for all: Supporting students with special needs in the music classroom. Retrieved from https://tspace.library.utoronto.ca/bitstream/1807/72239/1/ Manning_Ilana_R_201606_MT_MTRP.pdf

Ministry of Education Malaysia. (2013a). Malaysia education blueprint 2013-2025 pre-school to post school education. Retrieved from http://www.moe. gov.my/images/dasarkpm/articlefile_file_003108.pdf

Ministry of Education Malaysia. (2013b). Special education division ministry of education Malaysia, 1-29. Retrieved from https://www.moe.gov.my/images/Bahagianpendidikan-khas/Program-Pendidikan-Inklusif/ circularfile_file_001162.pdf

Mirani, S., \& Chunawala, S. (2015). Teachers' perceptions of dealing with mixed ability classrooms. 43-50. Retrieved from https://www.researchgate.net/publication/ 29251 3387_Teachers' Perceptions_of_Dealing_with_Mixed_Ability_Classrooms

Mumpuniarti. (2017). Challenges faced by teachers in teaching literacy and numeracy for slow learners. Journal of Sustainable Development, 10(3), 243-248. Retrieved from http://www.ccsenet.org/journal/index.php/jsd/article/view/65215/37306

Nasir, M.N.A. \& Efendi, A.N.A.E. (2016). Special education for children with disabilities in Malaysia: Progress and obstacles. Malaysian Journal of Society and Space, 12(10), 7887. Retrieved from http://www.ukm.my/geografia/images/upload/9.geografia-ogos16muhdnadhir-edam.pdf

Paul-Fitzpatrick, A. (2014). Implementing teaching strategies to students with difficulties in learning in a mainstream inner city school - Teachers' experiences. (Doctoral dissertation, University of the West Indies, Saint Augustine, Trinidad and Tobago). Retrieved from http://uwispace.sta.uwi.edu/dspace/handle /2139/39812 
Paul, P. B. (2016). Coping with slow learners. International Journal of Management and Applied Science, 2(12), 56-58. Retrieved from http://www.iraj.in/journal/journal_file /journal_pdf/-148490664556-58.pdf

Presseisen, B. Z. \& Kozulin, A. (1992). Mediated learning-- the contributions of Vygotsky and Feuerstein in theory and practice.

Seng, T. O. (2003). Mediated learning and pedagogy: applications of Feuerstein's theory in twenty-first century education. REACT, 22(1), 53-63.

Sharma, U., Forlin, C., Deppeler, J. \& Guang-xue, Y. (2013). Reforming teacher education for inclusion in developing countries in the asia-pacific region. Asian Journal of Inclusive Education, 1(1), 3-16. Retrieved from http://ajie-bd.net/wp-content/uploads/ 2016/08/ sharma.pdf

Shaw, S. R. (2010). Rescuing students from the slow learner trap. Principal leadership, 10(6), 12-16. Retrieved from https://eric.ed.gov/?id=EJ894654

Tzuriel, D. (2001). The Mediated Learning Experience (MLE) theory. Dynamic Assessment of Young Children. New York, NY: Plenum Publishers.

Udoba, H. A. (2014). Challenges faced by teachers when teaching learners with developmental disability. (Master's thesis, University of Oslo, Oslo, Norway). Retrieved from https://www.duo. uio.no/bitstream/handle/10852/42438/Master-thesis-Humphrey-2-2. pdf $?$ sequence $=1$

Uzair-ul-hassan, M., Hussain, M., Parveen, I. \& Souza, J.D. (2015). Exploring teachers' experiences and practices in inclusive classrooms of model schools. Journal of Theory and Practice in Education, 11(3), 894-915. Retrieved from http://eku.comu.edu.tr/ article/view/5000086275

Vorapanya, S. \& Dunlap, D. (2014). Inclusive education in Thailand: Practices and challenges. International Journal of Inclusive Education, 18(10), 1014-1028. Retrieved from https://eric.ed.gov/?id=EJ1037654

Wong, M. W. Y., \& Chik, M. P. Y. (2016). Teaching students with special educational needs in inclusive music classrooms: Experiences of music teachers in Hong Kong primary schools. Music Education Research, 18(2), 195-207. Retrieved from https://repository. hkbu.edu.hk/cgi/viewcontent.cgi?article=3962\&context=hkbu_staff_publication

Yadav, R. (2016). The impact of compensatory teaching to slow learners and improve their hidden skills. New Man International Journal of Multidisciplinary Studies, 3(8), 74-79. Retrieved from http://www.newmanpublication.com/admin/issue/ Articale/15\% 20New\%20Man\%20Publication\%20NMIJMS\%20August\%202016_www.newmanpu blication.pdf

Zuki, N.H.M. \& Rahman, N.S.N.A. (2016). Challenges Malaysian teachers face in the inclusion of autistic students in the normal classroom. Journal of Education and Social Sciences, 4, 33-41. Retrieved from http://jesoc.com/wp-content/uploads/ 2016/08/Edu30.pdf 


\section{APPENDIX}

\section{Interview Guide}

1. How long have you been teaching English language?

2. How long have you been teaching English language to slow learners?

3. How do you identify slow learners in your class?

4. What is your opinion on teaching English language to slow learners?

5. What is your opinion on teaching English language to slow learners, in an inclusive classroom?

6. How do you usually teach English language to slow learners?

7. What are the difficulties that you face when teaching English to slow learners? Can you give some examples of the difficulties?

8. How do you overcome those difficulties?

9. What are the problems slow learners faced in learning English language? 